\title{
Comparison of Procedural Laws of Executive Power Certificate of Fiduciary Guarantee and Guarantee of Mortgage Based on The Decision of The Constitutional Court
}

\author{
Inri Januar $^{1}$, Mochammad Bakri ${ }^{2}$, Rachmi Sulistyarini ${ }^{3}$, Budi Santoso ${ }^{4}$ \\ \{indrjanuar@yahoo.com¹, bakri_fhub@yahoo.com², rachmirini@yahoo.com ${ }^{3}$, \\ busan04@gmail.com $\left.{ }^{4}\right\}$ \\ ${ }^{1}$ Faculty of Law, Universitas Kristen Indonesia, Indonesia \\ ${ }^{2,3,4}$ Faculty of Law, Universitas Brawijaya , Indonesia
}

\begin{abstract}
The Constitutional Court has issued two decisions regarding the executorial power of the guarantee certificate, namely decision number 18 / PUU-XVII / 2019 regarding the procedural law for fiduciary security and number 21 / PUU-XVIII / 2020 regarding the right of mortgage. According to the court, the articles tested in the two decisions had different meanings even though the articles tested had the same text and context. These two decisions have an important role in the law of guarantee, which in principle provides convenience in the execution of the execution so that it is not equated with general procedural law. It is necessary to formulate a special procedural law for the implementation of the executorial power of the guarantee certificate which reflects protection, certainty and justice for both creditors and debtors after the two decisions.
\end{abstract}

Keywords: execution, legal protection,guarantee

\section{Introduction}

In the business world, economic actors cannot be separated from financial dependence or capital from other economic actors, this kind of relationship is also known as a legal relationship, which means that rules of the game must be made to protect the interests of each party. If one party is entitled to achievement (creditor), of course the other party is obliged to fulfill the achievement (debtor), if the achievement is not fulfilled then the debtor must be declared in default or in broken promise. With regard to default, so that the achievement can be fulfilled, the creditor will propose the fulfillment of the achievement either by asking the court or can just execute the collateral given by the debtor because the executorial title is attached (Inri Januar: 2016).

Guarantee has a very important position and benefits in supporting economic development, because the existence of this institution can provide benefits for creditor in the form of security for trade transactions and providing legal certainty for creditor (Sri Soedewi Masjhoen Sofwan: 1980). The purpose of the guarantee as stated by Adrian J Bradbrook is the purpose of a security 
interest is to cofer property rights upon someone to whom a debt is due (Adrian $\mathbf{J}$ Bradbrook:1991).

The emergence of various kinds of regulations related to pandemics has led to a discussion about whether the circumstances caused by the pandemic and / or laws and regulations make achievements postponed or can eliminate obligations and abolish the engagement. Fulfillment of performance is an obligation for the debtor in an engagement (schuld), while the penalty for not fulfilling the obligation is the emergence of juridical responsibility (haftung) (J Satrio: 1999) against the assets of the debtor or third party who bind themselves in an engagement. Against the law schuld provide deviation, this makes the debtor can be freed from carrying out his obligations and not getting a penalty. Deviations in the law cannot only delay obligations or even end the engagement (inri januar: 2020).

Especially in the current pandemic condition that is still ongoing where there are business activities that are limited by regulations issued by both the central and local governments. This situation will affect the ability of debtors who have made agreements prior to this pandemic. The essence of the agreement is whether the agreement was carried out well or ended up in default. It is in this state of default that the victim's condition must be recovered by carrying out an execution whenever a movable property (fiduciary, pawn) or immovable property (mortgage) has been placed in the agreement.

According to Jimly Asshiddiqie and M Ali Safa'at, initially there was only one sanction, namely criminal sanctions in the form of punishment in the narrow sense related to life, health or property. Along with the development of civil law, civil sanctions have also emerged which differentiate them from criminal sanctions, namely the character of the sanctions. In civil law, sanctions aim to provide reparations while criminal law sanctions are retributive in character or according to modern views, are prevention (deterrence, prevention).

When viewed from the procedure for imposing sanctions, in civil law the procedure is carried out with the actions of certain subjects who have an interest in the implementation of these sanctions, while in criminal law the procedures carried out in court are ex officio with organ actions, namely public prosecutors (Jimly Asshiddiqie dan M Ali Safa'at: 2014). The same view was expressed by Purnadi Purbacaraka and Soerjono Soekanto, Sanctions or penalties are punishment for those who have committed delict.

There are three kinds of Sanktum, namely:

1. As a remedy for the situation, it can be found in civil law in the case of acts against the law.

2. As a fulfillment of the situation, in civil law, especially agreements.

3. As a punishment in a broad sense, namely actions that are not classified into one of the types of sanctions mentioned above, for example:

a. In civil law an example is the matter of additional compensation ("aanvullende schadevergoeding").

b. In the field of state administrative law, namely in the form of dismissal from office or suspension of an employee ("administratieve maatregel").

c. In the field of criminal law as it is familiar, it is called punishment ("punishment").

Punishment in a narrow sense is meant as torture ("leed") which is differentiated between: 1. Real or material torture, for example the death penalty, a fine, confiscation and so on

2. Ideal or moral torture, for example the announcement of a judge's decision, revocation of rights and others" (Purnadi Purbacaraka, Soerjono Soekanto: 1978).

Aristoteles based his formulation of justice on three essences of natural law, namely Honeste Vivere, alterum non laedere, suum quique tribuere (living in dignity, not disturbing others and giving to people every part of it). He introduced a model of justice based on numerical 
equality (in principle, everyone is equal before the law) and proportional (in principle, giving everyone what is their right) as well as distributive justice and corrective justice. Proportional justice is similar to distributive justice in that it gives each person what he owes. Corrective justice focuses on correcting something that is wrong by providing compensation to the injured party.

The theory of corrective Justice teaches that everyone must have their rights protected and their condition restored so that there is a balance between justice and legal certainty which is the goal. On the basis of morality, the person who made a mistake must be forced through the law to restore the victim's condition as before. This remedy is by giving everyone a fix for the situation caused by the violation of their rights by others. Aristotle developed a concept of corrective Justice, which is a contrasting concept of justice which is readjusting or correcting. The term used by Cystotle is orthodokos. Literally the term means to straighten which can be applied to legal relations (sunallagmata) either voluntarily (hekosia) or forcibly (akosia) (quoted in the book Rosa Agustina: 2003).

In the material guarantee, it is evident that the party that wants to be protected is the creditor because the dispute occurs when the deitor does not fulfill his obligation. At that moment, the creditors have been damaged and must be restored to the state they should have been. With that is given the executorial power of the certificate of material guarantee which is the same as the inkracht verdict. Nowadays its existence is starting to be doubted, especially in a pandemic situation.

Guarantees and their execution in material guarantees, especially fiduciary guarantees and mortgages, have different characteristics from the implementation of execution in general. The Constitutional Court has issued two decisions examining the executorial power of fiduciary guarantees (Number 18 / PUU-XVII / 2019) and mortgage rights (number 21 / PUU-XVIII / 2020) if there is default. The two decisions can be judged contradictory, but according to the author, they can be said to be the same even though the court has arguments which state that the executorial power in fiduciary guarantees and mortgage rights cannot be equated. There are several forms of guarantee that are known both in the Civil Code (KUHPerdata) and outside the Civil Code. In the Civil Code, there are forms of pawning and mortgages while outside the Civil Code, there are mortgages, fiduciary security and warehouse receipts.

The main problem in the two decisions is the question of the phrase "executorial power", "the same as a court decision having permanent legal force" and the phrase "breach of promise". These phrases in the fiduciary guarantee law are contained in article 15 paragraph 2 as well as the explanation and article 15 paragraph 3, for the mortgage right law is contained in article 14 paragraph 3 and 20 paragraphs 1 . Articles relating to the position of the fiduciary guarantee certificate and a certificate of mortgage and in the case of default, execution can then be carried out is the spirit of the fiduciary guarantee law and mortgage rights in terms of ease of execution. The provisions of this paragraph are a manifestation of the facilities provided by law for creditors holding fiduciary security certificates and mortgages in the event that execution must be carried out. Ease of execution is given by considering the cost factor in the event of default.

\section{Research Methods}

The research used in this paper is normative research, namely research that analyzes the norms that exist in the fiduciary guarantee law and the mortgage rights law related to the two decisions of the constitutional court. In addition to norms, principles will also be used as 
references in this paper. The approach used is the statutory approach and conceptual approach. The research material is primary legal material (Peter Mahmud Marzuki: 2017). The analysis in this study was carried out with deductive arguments that depart from the norm and then applied to an existing event.

\section{Results and Discussion}

\subsection{Execution Power of Fiduciary Guarantee Certificate and Mortgage Rights}

The nature of the guarantee institution must be strong, that is, it has the characteristic that it can be defended against anyone who always follows the object and can be transferred, in addition to the validity of specialiteit requirements (there is an obligation under the object that is guaranteed to be specifically appointed regarding its type, location, area, limit, as evidenced by a measuring letter and others) and publicity requirements (there is an obligation to register in the public register) which guarantees a strong evidentiary value for me, imposition, then the promise can be carried out easily and the grossen has executive power (Sri Soedewi Masjhoen Sofwan: 1980).

Execution or implementation of a decision is an act that is carried out by force against the party who loses in a case and has permanent legal force (BHT). Subekti emphasized that execution is only attached after the BHT (res judicata) decision, the decision in question cannot be changed anymore so that the legal relationship between the parties in the case is (fixed and certain) forever. The meaning of the execution of the execution is if the person executed does not carry out the decision voluntarily (vrijwilig / free will), therefore the implementation of the decision must be enforced with the help of general forces, can ask for help from the police and even the military (Subekti: 1977).

Sometimes execution is not an act of carrying out a court decision but carrying out the implementation (execution) of product forms that are equated by law as decisions that have obtained permanent legal force, namely (M. Yahya Harahap: 2005):

1. Implementation of the first enforceable decision

Regarding this, it is regulated in article 180, paragraph 1 of the HIR or article 191 of the RBG

2. Implementation of the provisional decision

Regarding this is regulated in article 180 paragraph 1 HIR or 191 paragraph 1 RBG as well as articles 54 and $55 \mathrm{RV}$

3. Deed of peace

This is regulated in article 130 HIR or article 154 of the RBG

4. Execution of the groose deed

This is regulated in article 224 HIR or 258 RBG

5. Execution of mortgage and fiduciary security

Regarding this is regulated in Law number 4 of 1996 concerning mortgage rights and execution of fiduciary guarantees regulated in Law number 42 of 1999 concerning Fiduciary Security.

In both decisions the constitutional court has given the meaning to the phrase "executorial power" "is the same as a court decision having permanent legal force" and "default". Whether the executorial power of the material guarantee certificate is the same as the inkracht decision 
can be interpreted literally and rigidly. If you look at the considerations in the birth of the material guarantee, the executorial power of the material guarantee certificate must indeed be equated with the inkracht decision.

This consideration is carried out to cut time and costs in handling a material guarantee case if a default occurs so that it can be immediately implemented without proving whether the debtor is in default or not. In the decision number 18/PUU-XVII/2019 the court has eliminated the essence of the executorial power of the fiduciary guarantee certificate by changing the norm construction because in its decision to determine whether or not a default has to be done by agreement or legal remedies. Decision number 21/PUU-XVIII/2020 does not change the norm construction but provides considerations that seem to have changed the norm construction.

The concept of the phrase "executorial power" "equals a court decision having permanent legal force" has become a separate problem in the law of guarantee procedure because it equates the guarantee certificate with an inkracht court decision. In using this conceptual approach, the writer needs to refer to legal principles that are found in the views of scholars or legal doctrine or are not explicitly found in law (Peter Mahmud Marzuki: 2017).

The concept of equating the guarantee certificate with the inkracht verdict according to the author is incorrect. In the court process, evidence has been passed regarding whether the person who was guilty has been proven guilty or not, while in the guarantee certificate there is no proof because immediately the right of executorial power has been given since the certificate was issued. But it must also be considered from other aspects which are the characteristics of the material guarantee institution. Guarantee agencies are simple, easy, cheap and efficient. How sad it is for a guarantee institution that is expected to support economic progress, support credit activities, support investment activities, support public housing development activities, support protection for the weak economy, in which there are no characteristics and principles and requirements that can accommodate and balance activities various fields (Sri Soedewi Masjhoen Sofwan: 1980).

According to the provisions in article 24 paragraph 1 and 2 of the 1945 Constitution, it is the type of judicial power that is administered by the judiciary to enforce law and justice in the supreme court (judiciary). Meanwhile, according to the Fiduciary Guarantee Law, the institution that issues executive power is the ministry (executive). Of the two institutions (judiciary and executive) that issue executive power products may have different views on the concept of executive power in fiduciary guarantees and mortgages.

The guarantee agreement is a derivative agreement. A guarantee agreement is usually constructed as an accesoir agreement, which is always an agreement that is linked to the main service agreement on the main agreement. The position of the guarantee agreement, which is constructed as an access agreement, is to guarantee the strength of the guarantee institution for the security of credit extension by creditors. funds as an accesoir agreement receive legal consequences as well as other access agreements, namely (Sri Soedewi Masjhoen Sofwan: 1980)

a. depends on the main agreement

b. erase depends on the principal agreement

c. If the principal agreement is canceled, it will be canceled

d. follow the transfer of the main agreement

e. If the principal changes due to cessie, subrogation, then it is also transferred without any special submission.

There are things that make the possibility of a material guarantee certificate not absolutely equated with an inkracht court decision. This is when the principal agreement can be canceled, 
the derivative agreement is canceled as well as the articles in the law which are bound by the guarantee agreement.

In decision number 18 / PUU-XVII / 2019 the court is of the opinion that the executorial power of the fiduciary guarantee certificate is unconstitutional if it is not interpreted as default, there must be an agreement or legal remedy first. Then the execution of the execution must be in accordance with or refer to execution within the scope of the court. In this case the Constitutional Court has changed the norm construction in terms of the executorial power of the fiduciary guarantee certificate. Is it true that material guarantees cannot have a way of carrying out executions outside the judiciary in general? The authority stipulated in the fiduciary guarantee law is the specialist of court executions in general. The author assesses that the reference in the consideration of this decision is not appropriate to change the norm.

In decision number 21/PUU-XVIII/2020 the court does not want to change the norms against the same article being tested in relation to fiduciary guarantees. The Court is of the opinion that if there is a person who feels that his rights have been harmed due to coercive circumstances, then the executorial power of the mortgage certificate cannot automatically be exercised because that person has the right to file a lawsuit or challenge in accordance with Article 1865 of the civil code. Article 1865 applies in general or generalist while for material guarantee specialists apply. If there is a conflict, the provisions in the material guarantee can eliminate the provisions that apply in general. It is also inappropriate for mahakamah to use the basis of article 1865 Kitan of the civil law to change the context in guaranteeing mortgage rights in decision number 21/PUU-XVIII/2020.

The state of coercion here appears to eliminate the error in the concept of civil. A coercive situation is something that can prevent the debtor from being released from carrying out his obligations. Obligations that are released can be temporary or permanent in nature. According to Rahmat S.S Soemadipradja, being temporary means that it only temporarily suspends the obligations of the debtor, but after the force ends the debtor has the obligation to return to carry out the agreement. Permanent in nature, the meaning is to permanently eliminate the debtor's obligation because if the debtor's obligation is repaid after the situation has passed, the act will no longer have any benefit for the creditor. The latter characteristic can make the engagement null or void (Rahmat S.S Soemadipradja: 2010). There are several examples of articles in the Civil Code which state that an agreement is canceled due to coercive circumstances, namely articles 1545, 1553 and 1607 of the Civil Code.

The definition of a state of coercion can only be found in construction services regulations and goods and services procurement regulations which oblige parties to enter a force majeure clause. Force majeure in the construction service regulation is defined as an event that occurs beyond the willing and ability of the parties which causes losses to one of the parties, whereas in the regulations for procurement of goods and services force majeure is called force majeure, a condition that occurs outside the will of the parties so that the obligation those stipulated in the contract cannot be fulfilled (article 29 paragraph 1 number 10 Presidential Regulation No. 80 of 2003 which has been amended until the last Presidential Regulation number 95 of 2007).

If this compelling situation arises, the principal agreement can be canceled. If the principal agreement is canceled, the derivative agreement is canceled. The coercive situation in fiduciary is very likely to occur because the essence of fiduciary that distinguishes pawning is in the fiduciary that objects that are guaranteed are still in the control of the debtor to be exploited. The relationship between the ability to carry out obligations with objects that are guaranteed to have causality with a compelling state. If the collateralized object cannot be used either because of the condition of the object or environmental conditions that result in the object cannot be used, in this case the debtor is likely to be in a state of force. 
The guarantee of mortgage rights does have a difference with fiduciary security. Here there is no relationship between the object and the ability to pay of the debtor which is explicitly stated in the mortgage rights law. this kind of situation does not mean that a coercive situation cannot arise in the guarantee of the mortgage. In a pandemic situation where the government imposes restrictions on both business and non-business activities, the community means that there is a situation that is not reasonable and cannot also be said to be a business risk.

Between fiduciary security and mortgage rights can be linked between the force and the abolition of the same main agreement. The court should have stood in the same view on the same two circumstances in terms of the executorial power of the guarantee certificate. According to the author, there are no different circumstances regarding the norms in the two decisions. The two guarantees that distinguish only the shape or form of the collateral object.

\subsection{Transfer of Property Rights and Guarantee}

The second thing that according to the author can be of concern is when the court judges if the fiduciary guarantee has transferred ownership rights so that creditors through third parties can at will to carry out the execution (withdraw vehicles) while in guaranteeing the mortgage because the property is fixed and does not transfer property rights.

In principle, the guarantee is the repayment of the debt if the debtor does not fulfill his obligations, because the debt must be converted into money, the guarantee must also be in the form of money. This happens because there is a possibility that the proceeds from the sale of the guarantee can be more or less to pay off the debt. In all collateral, the collateral object cannot be owned by the creditor, all of which are regulated in article:

1. Article 1154 of the Civil Code "if the debtor or the person who gives the pledge does not fulfill his obligations, then the debtor is not allowed to own the goods as pawned".

2. Article 1178 of the Civil Code "all promises by which the debtor is authorized to have the object given in the mortgage is null and void".

3. Article 12 of the Mortgage Rights Law "The promise that gives authority to the holder of the Mortgage Rights to own the object of the Mortgage if the debtor defaults, is null and void".

4. Article 33 of the Fiduciary Guarantee Law "Any promise that authorizes the Giver of Fiduciary to own an object that becomes the object of the Fiduciary Guarantee if the debtor fails to promise, is null and void".

Guarantee is not an agreement to transfer someone's property rights to an object so that how can the law package a norm that can protect the interests of creditors and debtors. The consideration of the constitutional court number 18 / PUU-XVII / 2019 does not mention that because there has been a transfer of property rights under the fiduciary guarantee, the execution can be carried out by creditors, this consideration is obtained in the Constitutional Court decision number 21 / PUU-XVIII / 2020. In the consideration of decision 21 / PUU-XVIII / 2020 the Constitutional Court stated that basically article 15 paragraph 2 and 15 paragraphs 3 in the decision of the constitutional court number 18 / PUU-XVII / 2019 can be granted because there has been a transfer of property rights from the debtor to the creditor.

The principle of guarantee in every material guarantee is the same, namely that it cannot transfer ownership rights to the object to the creditor. The nature of this principal norm is compelling because it will invalidate any promise that gives creditor authority to have collateral. Therefore, the meaning of property rights in decisions number 18 / PUU-XVII / 2019 and number 21 / PUU-XVIII / 2020 should be the same.

The transfer of property rights in Indonesian law refers to article 584 of the Civil Code with a closed system. Transition occurs because the appointment and delivery which is preceded 
by the basis of the rights can be seen if the appointment or delivery depends on the obligatory agreement. If the basis of the right is an agreement to guarantee, then no transfer of ownership can occur by handing over the object.

In the transfer of property rights in Indonesia using a causal system that relies on the validity of levering on two conditions (R Subekti: 2014):

1. validity of the title on which the levering is based

2. The levering is carried out by the person who has the right to act independently of the goods in the lever

Furthermore, according to R Subekti, the obligatory agreement as referred to as title is only buying and selling, exchanging, and giving while zakelijk is the handover of objects.

There are four conditions for a surrender (Hasbullah Frieda Husni, 2002):

1. There is a material agreement, namely an agreement that causes the transfer of material rights, for example bezit, eigendom, mortgage pawning and others.

2. There must be a reason for the title or title as stated in article 584 kuhperdata, namely that the relationship can lead to the transfer of goods, for example due to sale and purchase agreements, exchange and other things.

3. There must be an authority to control an object which is the implementation of the principle of nemoplus, that is, a person cannot transfer a right beyond what is normally the owner.

4. Real submission and juridical submission

Real surrender is hand-to-hand surrender and what is surrendered is moving objects. juridical submission is carried out through land registration.

The concept of fiduciary security which states that they have transferred ownership is not appropriate because if the ownership rights are transferred, of course the owner can act freely on his own property. Acquisition of a vehicle by a creditor under a fiduciary guarantee does not constitute the essence of the execution as referred to in the guarantee law. Execution under guarantee is selling the object that is guaranteed to pay off the debt, this. Article that strengthens the opinion of the author is article 30 and the explanation of the fiduciary guarantee law. Article 30 and the explanation that the withdrawal of fiduciary collateral is a process before the execution is carried out so that it can be interpreted that the withdrawal of the fiduciary object that is carried out is not an execution because the execution has not occurred at the time of the withdrawal of the fiduciary object.

The concept of transfer of property rights in fiduciary guarantees and mortgages is the same, so that the court rulings contradicting the concept of transfer of property rights between two guarantees are incorrect. Because it departs from an inaccurate desidendi ratio, according to the author, the considerations and rulings of the constitutional court are wrong. It is wrong because the verdict is not based on existing evidence but is based on legal knowledge and analysis from the judges.

\section{Conclusion}

Based on the two issues that have been described, according to the author, the court was wrong in issuing decisions number 18 / PUU-XVII / 2019 and number 21 / PUU-XVIII / 2020 both in their considerations and guidelines. Because the decision of the constitutional court is final and binding, this decision must still be accepted. It is necessary to formulate a procedural 
law formula, especially guarantees that can accommodate the wishes of the parties so as not to feel disadvantaged. The Supreme Court Rule regarding simple lawsuit is one of the breakthroughs in civil procedural law in Indonesia but its scope is very narrow. How to make procedural law that represents the interests and debtors from a legal and economic standpoint

\section{References}

[1] 1945 constitution.

[2] Civil Code (Burgerlijk Wetbooek)

[3] Law of the Republik of Indonesia Number 4 of 1996 concerning mortgage right

[4] Law of the Republik of Indonesia Number 42 of 1999 concerning fiduciary guarantee

[5] Aristoteles "nicomachean ethics dalam Richard A Psoner, The Concept of Corective Jusstice in Recent Theories of Tort Law dalam Saul Leumore, Foundations of Tort Law (New York: Oxford University Press, 1994) hal. 59 dikutip dalam buku Rosa Agustina, Perbuatan Melawan Hukum, Pascasarjana Fakultas Hukum Universitas Indonesia, Jakarta, 2003, hal 27

[6] Asshiddiqie Jimly dan Safa'at M Ali, Hans Kelsen Teory about law, Konpres, Jakarta, 2014, hlm 46

[7] Bradbrook Adrian J, Australian Real Property Law, Sidney, The Law Book Company Limited, 1991, hlm 708.

[8] Harahap M. Yahya, Scope of Civil Execution Problems second edition, Sinar Grafika, Jakarta, 2005, hal. 6

[9] Hasbullah Frieda Husni, Civil Material Law, Rights that Provide Enjoyment, Ind hill Co, Jakarta, 2002, hlm 120.

[10] Purbacaraka Purnadi, Soekanto Soerjono, Regarding Legal Rule, Alumni, Bandung, 1978, Hlm 8486.

[11] Marzuki, Peter Mahmud, Research Method Edisi Revisi, Kencana, Jakarta, 2017, hlm. 181-182.

[12] Satrio J, General Engagement Law, Bandung: Alumni, 1999, hlm 21.

[13] Soemadipradja Rahmat S.S, Explanation of the Law About Forceful Situation, Gramedia, Jakarta, 2010, hlm 9

[14] Sofwan Sri Soedewi Masjhoen, Guarantee Law in Indonesia Principles of Law and Personal Guarantees,Jakarta : BPHN Departemen Kehakiman RI, 1980, Hal.2

[15] Subekti R, Various Agreements,Citra Aditya Bakti, Bandung, 2014, hlm 12.

[16] Subekti R, Civil Procedure Law, BPHN, Jakarta 1977, hal 130.

[17] http://ejournal.uki.ac.id/index.php/tora/article/view/1705/1521 accessed on 1 April 2021. 